\title{
INFORMED CONSENT FOR CASE REPORTS - AN ETHICAL PERSPECTIVE
}

\author{
Paulo Santos ${ }^{1}$, Alberto Hespanhol ${ }^{2}$
}

\begin{abstract}
The case report is a special type of scientific publication that focuses on a single patient, raising problems of confidentiality, as the exposure of the intimacy may facilitate identification of the participants. The legitimacy for the public disclosure derives from the informed consent, ensuring the preservation of patients' self-determination. In this article, we discuss aspects of autonomy as basic ethical principle, framing under the Portuguese Law. In the case reports, as in any clinical investigation, the will of the patient should prevail over the interests of research and researchers, even when he is unable to consent, like the minors, the disabled or the deceased, enforcing the legal rules and addressing to the active involvement of the guardians and the relatives.
\end{abstract}

Key words: autonomy, confidentiality, education for health care professionals, ethics committees, family

\section{Consentimiento informado para informes de caso - una perspectiva ética}

Resumen: El caso clínico es un tipo especial de la publicación científica que se centra en un solo individuo. Es ampliamente utilizado en la comunicación médica, tanto desde un punto de vista científico como pedagógico. Plantea problemas respecto a la confidencialidad en la medida en que la descripción de los detalles íntimos puede conducir a la identificación de los pacientes. La legitimidad de la presentación pública se deriva del consentimiento informado, que garantiza la preservación de la autodeterminación del paciente en cuestión. En este artículo, se discuten aspectos de la autonomía como principio ético básico a la luz de la legislación portuguesa. En los informes de casos, como en cualquier investigación, la voluntad del paciente debe prevalecer sobre los intereses de la investigación y de los investigadores, incluso si no puede consentir que en el caso de menores de edad, incapacitados o fallecidos, donde se asumen importantes cuestiones jurídicas y papel de los tutores y familia en este proceso.

Palabras clave: autonomía, confidencialidad, educación de los profesionales de la salud, comité de ética, familia

\section{Consentimento informado para relatórios de caso - uma perspectiva ética}

Resumo: O relato de caso é um tipo especial de publicação científica que se centra num único indivíduo. É muito utilizado na comunicação médica tanto do ponto de vista científico como pedagógico. Levanta problemas quanto à confidencialidade na medida em que a descrição dos pormenores íntimos pode levar à identificação dos doentes. A legitimidade para a apresentação pública deriva do consentimento informado, que garante a preservação da autodeterminação do doente envolvido. Neste artigo, discutimos os aspetos da autonomia como princípio ético basilar, à luz da Lei Portuguesa. Nos relatos de casos, como em qualquer investigação, a vontade do doente deve prevalecer sobre os interesses da investigação e dos investigadores, mesmo se incapaz para consentir como no caso dos menores, os incapazes ou os falecidos, onde assumem importância as questôes legais e o papel dos tutores e familiares neste processo.

Palavras-chave: autonomia, confidencialidade, educação de profissionais de saúde, comissão de ética, família

\footnotetext{
${ }^{1}$ General \& Family Medicine Unit, Department of Social Sciences and Health, Faculty of Medicine of University of Porto, Portugal Correspondence: psantosdr@med.up.pt

${ }^{2}$ Centre for Research in Health Technologies and Information Systems (CINTESIS), University of Porto, Portugal
} 
A case report is a scientific paper that deals with only one individual. It has been used since the beginning of Scientific Medicine and it has contributed significantly to the advancement of science both in terms of teaching and research. Numerous journals allow the publication of this type of articles. A search on MEDLINE for MeSH term "Case Reports" (Publication Type) lets us find more than 1.5 million articles. Figure 1 shows the evolution by year of publication of this sort of references in this database.

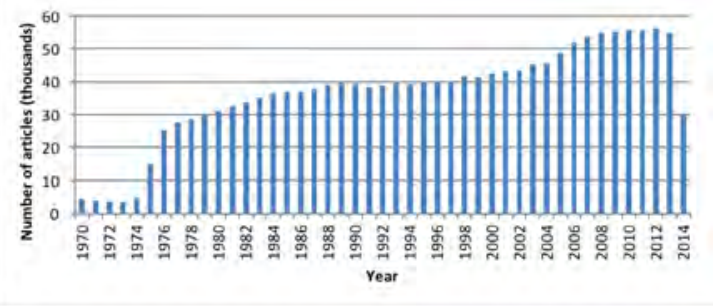

Figure 1 - Publications on MEDLINE (via PubMed) of 1970 to 2014 using the MeSH term "Case Reports" (Publication Type) (source: pubmed.com retrieved in $3 / 31 / 2015$ )

There are many reasons to publish a clinical case $(1,2)$ such as the uniqueness of the presentation, innovation in strategies for diagnosis, treatment or follow-up, or the appearance of adverse reactions. Also the impact that a health episode had upon the patient, the doctor or both may be a valid reason for reporting. Interestingly, the oldest case report indexed on MEDLINE (via PubMed) was published in the Journal of the American Medical Association in 1936, and it was about the first race of life: the duration of the migration of sperm through the uterine secretions (Carry W, 1936. JAMA. 106 (26): 2221-23).

Typically, the structure of a case report contains the description of a patient and his illness. It's complemented by a discussion, including a review of previous published works, systematic or not, and the authors' reflection, resulting in a scientific increment and an important source of medical knowledge in benefit of patients.

The ethical principles of non-maleficence and justice can be strengthened by the global evaluation of the rationality followed during the course of the disease, valuing the strengths and weaknesses for the patient and for the health team, and weighting the costs and the effectiveness of medical procedures.

From the ethical point of view, a case report raises issues at the level of patients' autonomy, considering the necessary informed consent, and the guarantees of confidentiality of doctor-patient relationship.

This article aims to discuss how the respect for patients' autonomy is assured in the process of publishing a case report.

\section{The Principle of Autonomy}

The principle of autonomy derives from the fundamental right of self-determination. In Medicine, it is embodied in the consent process which is inseparable from empowerment, since we can't realize the possibility that someone may validly take an option that he doesn't understand(3).

In clinical practice, it's common to have several viable alternatives for one health problem, requiring a balance of the benefits and the costs of each one. The patient will choose the solution that best satisfies his logic of values and preferences. Doctors take the responsibility to lead this process. They help to manage the different opinions, expectations and fears, demystifying false beliefs or prejudices, and collaborating to achieve the best decision. Patients are regarded as rational people, by the Kantian definition, and as such should be treated.

\section{Autonomy in Clinical Research Projects}

Since its first version in 1964, the Helsinki Declaration enshrines the primacy of the person, in his rights and interests, above any benefit that may arise from the investigation(4). Medical researchers are committed to the ethical duty to protect the life, health, dignity, integrity, self-determination, privacy and confidentiality of participants in studies.

In this context, it isn't licit to include a subject in a research project without his formal consent, regardless the level of intervention required. It is the responsibility of the researchers to inform the 
potential benefits and risks of the study, ensuring the safety of the procedures, and the involved resources. Unlike healthcare practice, in clinical research the primary interested part is the researcher, not the patient. It isn't uncommon that the participant doesn't benefit from the results, at least immediately or directly, calling to the selfless character of general health promotion through the important contribution to the increment of medical knowledge.

The information form includes these and other issues that are relevant in this particular context, in a clear and simple language, easily understood by the patient, less used to the medical or research jargon. It ends with the unequivocal expression of patient's own will in participating in the project. The informed (because it was) consent (because he accepts) is registered in written form, usually with two copies, one for the signatory and another for the investigator. Regardless of the signature on the paper, the consent process is a continuous interaction between both parts, questioned and renewed at any time.

\section{Autonomy in a Case Report}

A case report corresponds to an investigation in which data from a single patient are worked into a scientific reflection format.

The International Committee of Editors of Medical Journals regularly publishes recommendations for the publication of scientific $\operatorname{articles}(5)$ that are followed by most of the editorial offices and consequently by the authors who wish to publish their articles. On the typology of case reports, it defends the right to privacy and the requirement for obtaining an informed consent in written form. Nevertheless, all nominal elements of identification should be removed except if relevant for the clinical evaluation. Also the Committee on Publication Ethics (COPE) calls for special attention on the publication of case reports and photographs, where patients may recognise themselves or be identified by others, imposing to authors the absolute obligation to obtain a written con$\operatorname{sent}(6)$.

Portuguese law defines personal data as "any information, of any nature whatsoever and re- gardless of the respective support relating to an identified or which can be identified, directly or indirectly, in particular by reference to an identification number or to one or more factors specific to his physical, physiological, mental identity, economic, cultural or social" (7). In United States(8), Federal Regulations defined a set of identifiers that should be concealed to assure the confidentiality (table 1).

Our experience as members of a committee of ethics tells that it's common to find reports with the patients' birth date, for instance, when the clinical variable that really matters for analysis is the age. Thinking about the difference between a nominal identifier and a study variable is a simple way of correcting this difficulty. Some of these identifiers aren't directly related to medical research but it's possible they are registered in clinical files and the same attention is required.

Table 1 - Identifiers of the Privacy Act (adapted from Standards for Privacy of Individually Identifiable Health Information.2002 US Federal Register /

Names

Postal address information (other than town or city, State, and zip code)

All elements of dates, except year (including birth date and death date)

Telephone numbers;

Fax numbers;

Electronic mail addresses;

Social security numbers;

Medical record numbers;

Health plan beneficiary numbers;

Account numbers;

Certificate/license numbers;

Vehicle identifiers and serial numbers, including license plate numbers;

Device identifiers and serial numbers;

Web Universal Resource Locators (URLs);

Internet Protocol (IP) address numbers;

Biometric identifiers, including finger and voice prints; and

Full face photographic images and any comparable images.

Vol. 65, No. 250 - http:/www.gpo.gov/fdsys/ pkg/FR-2000-12-28/pdf/00-32678.pdf, retrieved at $4 / 24 / 2015$ 
Regardless of the anonymity of the patient, health data in a case report is intrinsically related to his private life. It has a sensitive nature and its use requires a clear justification of legitimacy that only the proper expressed consent can provide(9). Variables like genetic data or race are specially protected in many countries and its treatment follows specific rules.

If we are publishing a case of a skin disease in an 80 years old lady, references to her gynaecological history may or may not have interest. The adequacy of the reported data to the proposed aims is also a condition of legitimacy, and the researcher must justify such use.

On the other hand, certain sequences of events may generate sufficiently strong evidence for the identification of the participants, as the case of the woman who saw the story of her life exposed in the media after a journalistic investigation based on data published as a case report(10), or another example where it was the methodology of the scientific publication which exposed the identity of patient with negative consequences in her life(11). The confidentiality of the medical act is highly valued by patients(12) and an ethical and deontological pillar of health professionals. The definition of what is relevant and what is excessive must be weighted for each case, combining the needed information with the duty of confidentiality. Journal editors have a role in this discussion as the last guarantee of the compliance with the law and with this ethical principle(6).

\subsection{Autonomy in Special Cases}

The principle of autonomy prevails even if patient is incapable of state his / her own consent, expressly, freely and informed.

In the case of minors (in Portuguese Law, under 16 years old) or otherwise legally incompetent, the parents / guardians assume the responsibility for health management with the duty to promote their well-being. Also in a research project, they are responsible for validating the informed consent(13), notwithstanding the opinion of the patient can be integrated within the limits of its age and capacity of understanding.
In this group there is an increased responsibility that derives, on one hand, from some difficulty of parents / guardians to decide for the subject(14), and, on the other hand, from the vulnerability of these participants(15) which, accepted as ethical principle, enshrines the duty of a positive discrimination in their favour.

The vulnerability is also a relevant issue in cases where the attending physician is the one who recruits patients for the research. There are two main reasons to agree on research participation: altruism, directly related to the feeling of doing good to others; and the trade-offs, as direct financial reimbursement or improvement in access to health services, treatments or diagnostic elements(16). The asymmetry of doctor-patient relationship (17) can lead to an obstacle in the refusal to participate, which may be perceived as conditioner of it, despite the common phrase in the consent forms that ensures that no prejudice can result from its non-acceptance.

How will then be ethical to ask for the inclusion of a patient in an investigation when the researcher is the attending doctor? The Royal College of Physicians' guidelines on the practice of ethics' committees on medical research with humans solves this issue by stating that both the health professional and the patient, must be aware of the real possibility that the priorities of the research process overlap customized healthcare (18). The process should be conducted with truth and transparency, keeping both situations apart, as far as possible.

Another question is the relatives' participation in information-sharing and decision making. This is especially important in primary health care, where the person-centred approach is orientated to the individual, his/her family, and their community, allowing some blurring of personal boundaries.

In fact, the whole process of informed consent implies that sufficient time is given to subjects to help the reflection towards a weighted and responsible decision. The patient can advise from whomever he wants, whether a professional or not. It is common the patient come to the office accompanied by relatives, or other people seen as important for him, introducing himself a third 
element in the decision-making process. These dynamics of social relations and its integration in the decision-making process are elements that enhance the autonomy of their own and as such ethically acceptable(19).

A special case is the publication of a case report of a deceased patient. The first goal of medical science is to cure the disease, restoring the patient to the best possible health condition. For a long time, disability and death were seen as a failure. This attitude of denial about the inevitability of death remains common in health professionals and in the overall social thinking(20). Speaking of death refers to the fear of our own death, which may not be resolved in each of us(21).

Since the ancient Greeks we know we can learn a lot from the dead. "Mortui vivos docent" justified the anatomical dissection, which retains its current both in the health professionals' education as in the acquisition of new knowledge. In the last decades, medical knowledge was enhanced by the integration of the social and behaviour sciences. The post-mortem analysis accompanied this evolution beyond the anatomopathological cause of death to the integration of mourning processes, in a way that promotes excellence in health care for the benefit of all.

It is supposed that the intention to report a case of a deceased patient had been discussed with him and consented was obtained, respecting the principle of the autonomy. However it's not difficult to imagine a scenario where there was no opportunity to do it timely, due to an acceleration of intrinsic process of the disease, or because just after death, the necessary elements for a reasoned scientific reflection had combined each other. The COPE statement opens the possibility to publish without patients' explicit consent if the importance of the report for public health exceeds possible harms, if obtaining the consent is very difficult or even impossible, and if the likelihood of patient's disapproval is minimal (6).

Journals such as the British Medical Journal $(\mathrm{BMJ})$ case reports require that in such cases the consent is obtained through contact with a family member, preferably the next of kin(22). The Portuguese law(23), however, states that the health data belong to the holder both in life and after death, and it isn't liable to succession, disabling the family to consent in its use. In this sense only the informed consent, free and clear, of his own could authorize the publication of his medical history. However, there is an exception for public health services. Information contained in clinical files under the custody of public institutions is classified as nominative documents(7). Under such classification, the access is possible directly by patient or who has his permission, or by who demonstrates a direct, personal and legitimate interest sufficiently relevant. This relevance must be unequivocally proven on the basis of the public interest considerations outweigh the possible harms. Healthcare provider must justify to the responsible for access to information the relevance of the clinical report to get the necessary authorization to access to patient's data, allowing its publication.

Contact with family members isn't mandatory in the Portuguese legal framework. However, there are two points to reflect.

On the one hand, it is possible that patient in life has expressed in some way his wish regarding participation in research projects and such information may be in possession of family. Inquire about it in the convivial who shared patient's intimacy while lived is to respect his autonomy. Even without the assumed expression, relatives can translate the implicit will of the deceased. In a study of patients in emergency where informed consent of patient wasn't possible to obtain prior to inclusion in the study, only $0.7 \%$ of patients after recovery of consciousness took a different position to the one that had been taken by their relatives(24).

On the other hand, a case report is a memory about the patient's health history. This memory is shared by the healthcare provider and by others who lived actively the process of disease, in a triangulation of all known and accepted of mutual accountability, understanding the patients' needs and answering them as far as possible. The good acceptance of patients, their relatives and caregivers to participate in studies about end of life, when this sensitivity is incorporated, also points to positive effects of this interaction(25), 
even when the interview is conducted after the death(26), where it may facilitate the mourning process, for benefit of all.

Anyway, the publication of a case report in which it has not been possible to obtain valid informed consent can be sent prior to the Ethics Committee of the institution which shall take a decision on the legitimacy of the publication $(27,28)$.

\section{Conclusion}

Publishing a clinical case is a scientific exercise that may promote quality in health care, and benefits for patients, providers and health systems.

Respect of autonomy establishes the obtainment of written informed consent. More than a form read and signed by the parties, it should be a continuous process based on trust and mutual respect, reflecting the effective communication between researchers and patients. Information about the goals, procedures, strategies and methods are transmitted with clarity and truth, observing a time long enough for reflection and assuring the self-ownership of the decision about participation.
Even when the patients are unable to consent, the principle of autonomy prevails. In these special cases, legal rules and ethical counselling are rather important to confirm at each moment that the protection of the individual participant is always above the interests of the investigation or of the researcher.

\section{Acknowledgments}

We thank to Dra Evelyn Oliveira for the English language review of the manuscript.

\section{Competing Interests}

Authors have declared that no competing interests exist.

\section{Author's contributions}

All authors managed the literature searches and contributed to the writing of the manuscript. All authors read and approved the final manuscript. 


\section{References}

1. Jalalian M. Why publish a medical case report? Electronic physician 2014 Apr-Jun; 6(2): 786-787. PubMed PMID: 25763146. Pubmed Central PMCID: 4324273.

2. McCarthy LH, Reilly KE. How to write a case report. Family medicine 2000 Mar; 32(3): 190-195. PubMed PMID: 10726220 .

3. Miller BL. Authonomy. In: Post SG, editor. Encyclopedia of bioethics, $1.3^{\text {rd }}$ ed. New York: Macmillan Reference USA; 2004: 246-251.

4. World Medical Association. World Medical Association Declaration of Helsinki: ethical principles for medical research involving human subjects. JAMA 2013 Nov 27; 310(20): 2191-2194. PubMed PMID: 24141714.

5. International Committee of Medical Journal Editors (ICMJE). Recommendations for the Conduct, Reporting, Editing, and Publication of Scholarly Work in Medical Journals. International Committee of Medical Journal Editors 2014; p. 17.

6. Committee on Publication Ethics (COPE). Code of conduct and best practice guidelines for journal editors. Available at http://www.publicationethics.org/files/Code\%20of\%20Conduct_2.pdf, accessed in September/2015. 2011.

7. Brazil. Regula o acesso aos documentos administrativos e a sua reutilização, Lei 46/2007 de 24 de Agosto (2007).

8. Standards for Privacy of Individually Identifiable Health Information, 45 CFR Parts 160 and 164 - RIN 0991-AB14 (2002).

9. CNPD. Deliberaçáo n. ${ }^{\circ}$ 227/2007 - Aplicável aos tratamentos de dados pessoais efectuados no âmbito de estudos de investigação científica na área da saúde, 2007; p. 15.

10. Kluemper NS. Published case reports: one woman's account of having her confidentiality violated. Journal of interpersonal violence 2014 Dec; 29(18): 3232-3244. PubMed PMID: 24902594.

11. Putnam FW. Jane Doe: a cautionary tale for case reports. Journal of interpersonal violence 2014 Dec; 29(18): 3277-3289. PubMed PMID: 24879652.

12. Jones C. The utilitarian argument for medical confidentiality: a pilot study of patients' views. J Med Ethics 2003 Dec; 29(6): 348-352. PubMed PMID: 14662814. Pubmed Central PMCID: 1733815.

13. World Medical Association. WMA Declaration of Lisbon on the Rights of the Patient, adopted by the 34 th World Medical Assembly, Lisbon, Portugal, September/October 1981, and amended by the 47th WMA General Assembly, Bali, Indonesia, September 1995, and editorially revised by the 171st WMA Council Session, Santiago, Chile, October 2005, and reaffirmed by the 200th WMA Council Session, Oslo, Norway, April 2015. 2015.

14. Bailey DB Jr, Raspa M, Wheeler A, Edwards A, Bishop E, Bann C, et al. Parent ratings of ability to consent for clinical trials in fragile x syndrome. Journal of empirical research on human research ethics JERHRE 2014 Jul; 9(3): 18-28. PubMed PMID: 25422596. Pubmed Central PMCID: 4240639.

15. McDonald KE, Kidney CA. What is right? Ethics in intellectual disabilities research. Journal of Policy and Practice in Intellectual Disabilities 2012; 9(1): 27-39.

16. Dainesi SM, Goldbaum M. Reasons behind the participation in biomedical research: a brief review. Brazilian journal of epidemiology 2014 Dec; 17(4): 842-851. PubMed PMID: 25388485.

17. Scott JG, Scott RG, Miller WL, Stange KC, Crabtree BF. Healing relationships and the existential philosophy of Martin Buber. Philosophy, ethics, and humanities in medicine PEHM 2009; 4: 11. PubMed PMID: 19678950. Pubmed Central PMCID: 2733137.

18. Royal College of Physicians of London. Guidelines on the practice of ethics committees in medical research with human participants. $4^{\text {th }}$ ed. London: Royal College of Physicians of London; 2007.

19. Groll D. Four models of family interests. Pediatrics 2014 Oct; 134 Suppl 2: S81-S86. PubMed PMID: 25274879.

20. Rita de Cássia M. O estudo da morte e dos cuidados paliativos: uma experiência didática no currículo de medicina. Revista Brasileira de Educação Médica 2013; 37(2): 298-307.

21. Vianna A, Piccelli H. O estudante, o médico e o professor de medicina perante a morte e o paciente terminal. Rev Assoc Med Bras 1998; 44(1): 21-7.

22. BMJ. BMJ Case Reports - instructions for authors: BMJ Publishing Group Ltd; 2015 (08-05-2015). Available from: http://casereports.bmj.com/site/about/guidelines.xhtml.

23. Brazil. Informação genética pessoal e informação de saúde, Lei 12/2005 de 26 de Janeiro (2005).

24. Harvey SE, Elbourne D, Ashcroft J, Jones CM, Rowan K. Informed consent in clinical trials in critical care: experience from the PAC-Man Study. Intensive care medicine 2006 Dec; 32(12): 2020-2025. PubMed PMID: 17019555.

25. Gysels MH, Evans C, Higginson IJ. Patient, caregiver, health professional and researcher views and experiences of participating in research at the end of life: a critical interpretive synthesis of the literature. BMC Med Res Methodol 2012; 12: 123. PubMed PMID: 22900965. Pubmed Central PMCID: 3489694. 
Informed Consent for Case Reports - an Ethical Perspective - Paulo Santos, Alberto Hespanhol

26. Stiel S, Heckel M, Bussmann S, Weber M, Ostgathe C. End-of-life care research with bereaved informal caregivers analysis of recruitment strategy and participation rate from a multi-centre validation study. BMC palliative care 2015; 14: 21. PubMed PMID: 25934560. Pubmed Central PMCID: 4422133.

27. Gagnier JJ, Kienle G, Altman DG, Moher D, Sox H, Riley D, et al. The CARE guidelines: consensus-based clinical case reporting guideline development. BMJ case reports 2013 October 23.

28. Jansen TC, Kompanje EJ, Druml C, Menon DK, Wiedermann CJ, Bakker J. Deferred consent in emergency intensive care research: what if the patient dies early? Use the data or not? Intensive care medicine 2007 May; 33(5): 894-900. PubMed PMID: 17342513. Pubmed Central PMCID: 1964781.

Received: January 12, 2016

Accepted: March 3, 2016 